DIFUSI

Volume 1, No. 2, Juli 2018

\title{
PEMANFAATAN SOFTWARE FOTOGRAFI UNTUK BERWIRAUSAHA MOBILE DIGITAL PRINTING
}

\author{
Fitri Diani ${ }^{1)}$, Irwan Setiawan ${ }^{2)}$ \\ 1,2 Jurusan Teknik Komputer dan Informatika, Politeknik Negeri Bandung, \\ e-mail: ${ }^{1)}$ fitri@jtk.polban.ac.id, ${ }^{2)}$ irwan@jtk.polban.ac.id
}

\begin{abstract}
Abstrak
Karang Taruna merupakan wadah pembinaan dan pengembangan serta pemberdayaan dalam upaya mengembangkan kegiatan ekonomis produktif dengan pendayagunaan semua potensi yang tersedia di lingkungan baik sumber daya manusia maupun sumber daya alam yang telah ada. Karang Taruna RW 07 dan Karang Taruna RW 11 Desa Karyawangi Kecamatan Parompong, merupakan Karang Taruna yang memiliki anggota sebanyak 20 orang terdiri dari usia 15-40 tahun, dengan rata-rata pendidikan terakhir adalah SMP atau sederajat. Keterbatasan ilmu dan modal menjadikan kedua karang taruna tersebut kurang berkembang dan tidak dapat memenuhi fungsinya. Pada kegiatan ini dilaksanakan kegiatan dengan tema "Pemanfaatan Software Fotografi untuk Berwirausaha Mobile Printing". Software fotografi mobile yang digunakan adalah Software TouchReTouch, StickIt, BackgroundEraser, AthumbCut, dan PicsArt. Pendekatan transfer pengetahuan kepada mitra menggunakan Nonaka's Model. Metoda pelaksanaan kegiatan berupa pelatihan dan workshop. Pelatihan yang diberikan antara lain pelatihan Desain Grafis dan Kewirausahaan, sedangkan workshop yang diberikan meliputi praktik desain dan kewirausahaan. Setelah kegiatan pelatihan dan workshop, dilakukan monitoring dan pembimbingan terhadap mitra. Dampak dari kegiatan ini adalah meningkatnya kemampuan individu / kelompok yang dibuktika dengan dapat memperbaiki kinerja organisasi dalam mencapai fungsinya di masyarakat melalui kegiatan praktik secara langsung. Praktik ini sebagai alat untuk menguji kesuksesan transfer pengetahuan kepada mitra dalam mengimplementasikan pengetahuan yang sudah didapatkan selama pelatihan.
\end{abstract}

Kata kunci : Karang Taruna, Fotografi, Entrepreneurship, Mobile Digital Printing

\section{PENDAhuluan}

\subsection{Latar Belakang}

Karang taruna adalah organisasi organisasi kepemudaan di Indonesia. Karang taruna merupakan wadah pengembangan generasi muda nonpartisan, yang tumbuh atas dasar kesadaran dan rasa tanggung jawab sosial dari, oleh dan untuk masyarakat khususnya generasi muda di wilayah / desa / kelurahan atau komunitas sosial sederajat. Sebagai wadah organisasi sosial kepemudaan. Karang Taruna merupakan wadah pembinaan dan pengembangan serta pemberdayaan dalam upaya mengembangkan kegiatan ekonomis produktif dengan pendayagunaan semua potensi yang tersedia di lingkungan baik sumber daya manusia maupun sumber daya alam yang telah ada.

Keberadaan karang taruna di masyarakat memiliki peran dan tanggung jawab yang cukup penting. Karang taruna diharapkan dapat mendeteksi permasalahan yang terjadi di masyarakat dengan lebih cepat. Oleh karenanya karang taruna harus dapat lebih peka terhadap lingkungan di sekitarnya, dan mencegah hal-hal negatif yang akan timbul di kemudian hari. Salah 
satu fungsi pokok karang taruna di masyarakat adalah pemupuk kreativitas generasi muda sehingga dapat mengurangi jumlah pengangguran di masyarakat, mengurangi konflik antar pemuda, menciptakan kelompok pemuda yang aktif dan produktif.

Karang Taruna RW 07 dan Karang Taruna RW 07 desa Karyawangi Kecamatan Parompong merupakan kelompok Karang Taruna yang masingmasing memiliki anggota sebanyak 20 orang yang terdiri dari usia 15-40 tahun, dengan rata-rata pendidikan terakhir adalah SMP atau sederajat. Keterbatasan ilmu dan modal berupa dana dan sumber daya lainnya, menjadikan kedua karang taruna tersebut kurang berkembang dan tidak dapat memenuhi fungsinya sebagai mana mestinya. Hal tersebut sangat disayangkan sekali mengingat keberadaan karang taruna tersebut berada di daerah Parompong, Kabupaten Bandung Barat, yang memiliki potensi daerah yang cukup baik. Industri besar dan sedang banyak terdapat di Padalarang, Kota Kabupaten Bandung Barat. Pengembangan industri kecil dan rumah tangga pun banyak terdapat di Parompong. Potensi daerah tersebut dapat menjadi salah satu peluang bagi para anggota karang taruna untuk berwirausaha dan membantu meningkatkan perekonomian masyarakat.

Kegiatan merumuskan persoalan prioritas telah dilakukan bersama-sama dengan perwakilan dari masing-masing karang taruna dan didapatkan kesepakatan bahwa salah satu peluang yang dapat dimanfaatkan oleh para anggota karang taruna yang ingin berwirausaha adalah pemanfaatan software fotografi yang memiliki daya jual dengan membuat usaha digital printing secara mobile. Dengan adanya daya tarik tempat wisata, jumlah masyarakat, serta kemudahan dalam melakukan bisnis, usaha ini dinilai paling realistis untuk dijalankan, dan yang paling utama usaha ini dinilai tidak memerlukan banyak modal.

\subsection{Target dan Luaran}

Target yang diharapkan dari kegiatan pengabdian ini adalah :

1. Meningkatkan pengetahuan mitra mengenai pengetahuan dan kompetensi mitra untuk menggunakan software fotografi maupun multimedia sederhana sampai pada tahap aplikasinya dalam editing materi foto;

2. Mitra dapat memanfaatkan software fotografi dan design untuk melakukan wirausaha mandiri;

3. Menumbuhkan kesadaran dan semangat berwirausaha;

Luaran dari kegiatan pengabdian ini adalah:

1. Tersedianya materi pelatihan penggunaan Software fotografi mobile menggunakan Software StickIt;

2. Tersedianya materi singkat Pengenalan Kewirausahaan;

3. Tersedianya alat ukur untuk mengetahui ketercapaian program;

4. Hasil desain yang dibuat oleh peserta pelatihan.

\section{METODE KEGIATAN}

\subsection{Tahapan Kegiatan, Keterlibatan Personil dan Luaran Kegiatan}

Seperti dapat dilihat pada Gambar 1, pelaksanaan kegiatan terdiri dari 3 kegiatan utama, yaitu Persiapan, Pelaksanaan, dan Akhir kegiatan. Gambaran tahapan kegiatan, keterlibatan personil dan luaran kegiatan dapat dilihat pada Gambar 1.

\subsection{Bentuk Partisipasi Mitra}

Dukungan mitra dalam kegiatan ini sangat besar sehingga dapat membanttu tercapainya target dan tujuan yang sudah disusun. Bentuk partisipasi mitra dalam kegiatan ini antara lain:

1. Hadir dalam pelatihan tepat waktu;

2. Berperan serta aktif dalam proses belajar mengajar;

3. Bersedia untuk mengikuti semua tahapan kegiatan;

4. Memberikan feedback sebagai bahan 
DIFUSI

Volume 1, No. 2, Juli 2018

evaluasi kegiatan.

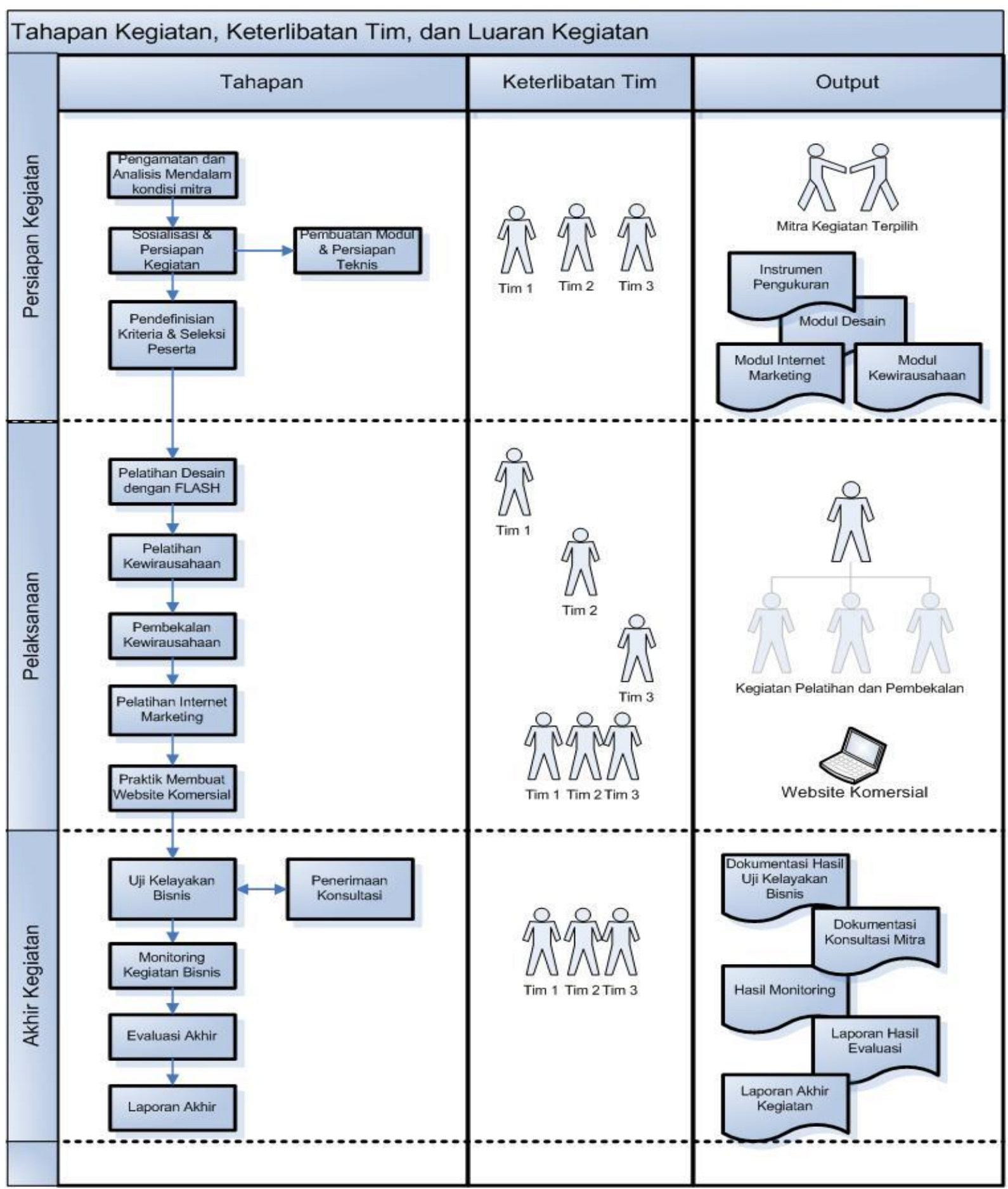

Gambar 1 Metode Pendekatan dan Prosedur Kerja 
DIFUSI

Volume 1, No. 2, Juli 2018

\subsection{Gambaran Transfer Pengetahuan kepada Mitra}

Proses pemilihan transfer pengetahuan kepada Mitra merupakan salah satu faktor yang cukup penting untuk menjamin bahwa pengetahuan tersampaikan dengan baik. Metode yang digunakan untuk proses transfer pengetahuan kepada Mitra menggunakan model Nonaka's seperti dapat dilihat pada Gambar 2. Pendekatan transfer pengetahuan kepada mitra menggunakan kegiatan :
1) Sosialisasi
2) Eksternalisasi
3) Internalisasi
4) Kombinasi.

\section{HASIL DAN PEMBAHASAN}

Kegiatan Pengabdian Kepada Masyarakat telah berhasil dilaksanakan dengan baik dan lancar. Evaluasi mendalam terhadap permasalahan yang dihadapi mitra kegiatan pengabdian ini didapat informasi sebagai berikut :

1. Pengetahuan tentang teknologi yang masih minim, sebagian peserta merasa "gaptek";

2. Dapat memaksimalkan pendapatan mitra;

3. Pemanfaatan alat telekomunikasi belum optimal;

4. Minimnya pengetahuan tentang peluang dan keuntungan berwirausaha secara online;

5. Permasalahan modal yang tidak memadai.

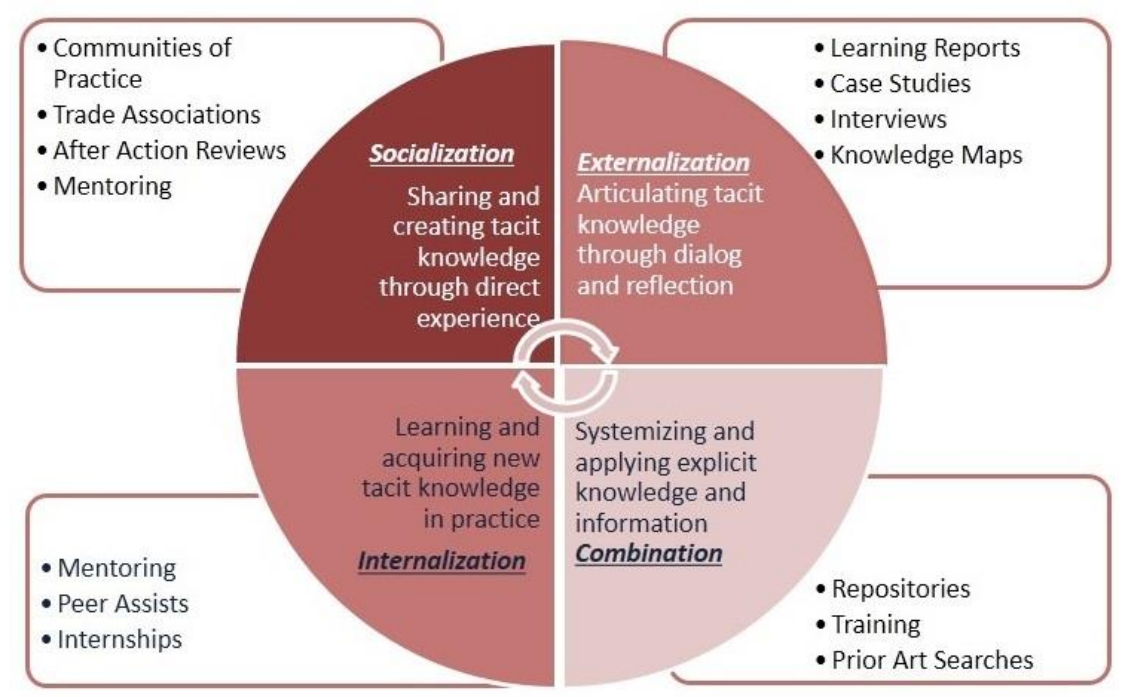

Gambar 2 Transfer Pengetahuan kepada Mitra

\subsection{Profil peserta kegiatan Pengabdian Kepada Masyarakat}

Kegiatan pengabdian kepada masyarakat diikuti oleh 19 orang yang berasal dari 2 mitra Karang Taruna yang terdiri dari 10 orang laki-laki dan 9 orang perempuan. Profil peserta kegiatan

berdasarkan usia, seperti dapat dilihat pada sebagai berikut: 


\section{SEBARAN USIA PESERTA}

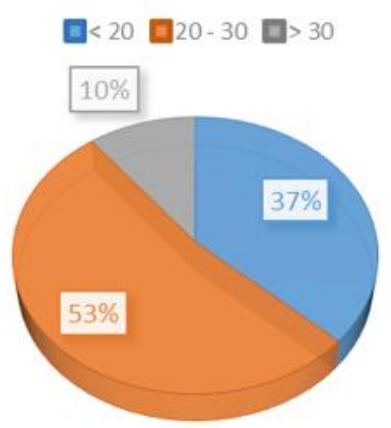

Rentang usia peserta terbanyak berada pada rentang usia 20-30 tahun sebanyak 53\%. Sebaran lengkap usia peserta dapat dilihat sebagai berikut:

1. Rentang tingkat pendidikan peserta terbanyak berada pada rentang pendidikan setara SMA sebanyak $63 \%$ (12 orang). Sebaran lengkap tingkat pendidikan peserta dapat dilihat sebagai berikut:

\section{Sebaran Tingkat Pendidikan}

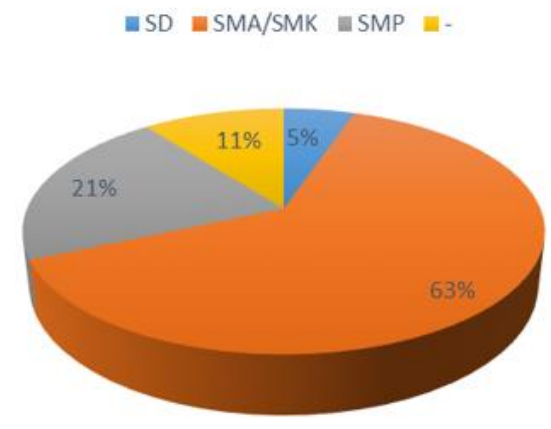

1. Sebaran profesi peserta terbanyak adalah tidak bekerja sebanyak 26\% (5 orang). Sebaran lengkap profesi peserta dapat dilihat sebagai berikut:

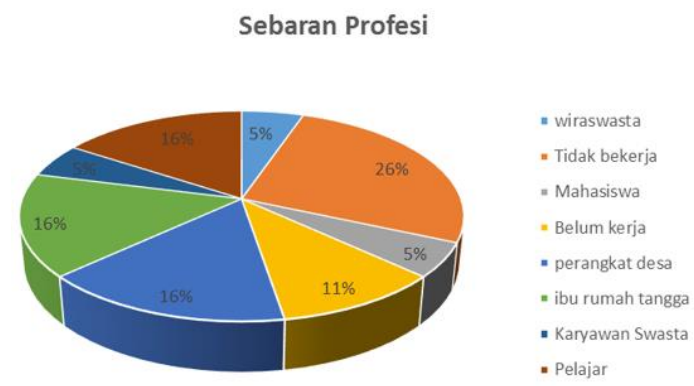

Profil intensitas peserta kegiatan dalam menggunakan teknologi didominasi oleh peserta yang biasa menggunakan teknologi dan berinteraksi dengan gadget (seperti dapat dilihat pada gambar berikut).

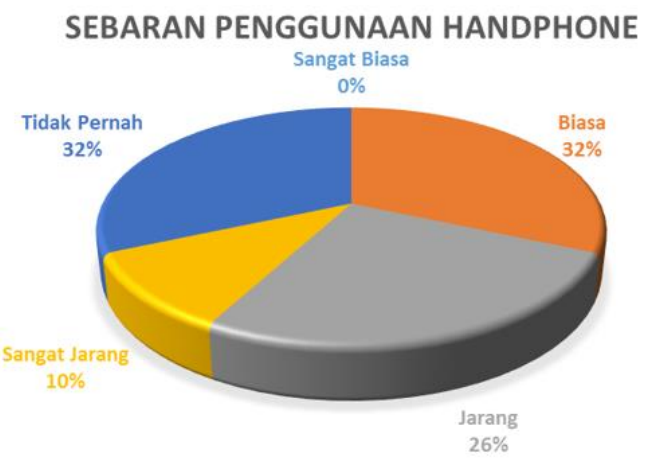

\subsection{Analisis Pasca Kegiatan Pelatihan}

Kuesioner pasca pelaksanaan kegiatan Pengabdian kepada Masyarakat ini dibuat sebanyak 2 (dua) bagian, yaitu :

1. Untuk menilai pelaksanaan kegiatan secara umum;

2. Untuk menilai konten / materi yang diberikan.

Hasil analisis pelaksanaan kegiatan secara umum diantaranya:

1. Sebanyak $92 \%$ peserta menilai kegiatan terlaksanakan dengan sangat baik dan sebanyak $8 \%$ menilai kegiatan terlaksana dengan baik.

2. Sebanyak $5 \%$ peserta menilai materi yang diberikan sangat baik dan sebanyak 95\% menilai materi yang diberikan baik.

3. Sebanyak $5 \%$ peserta menilai pemateri menyampaikan materi dengan sangat baik dan sebanyak 95\% menilai pemateri menyampaikan materi dengan baik.

4. Sebanyak $47 \%$ peserta menilai sangat setuju bahwa kegiatan ini sangat bermanfaat dan sebanyak 53\% menilai setuju bahwa kegiatan ini bermanfaat.

5. Sebanyak $47 \%$ peserta menilai sangat setuju bahwa ilmu yang didapat dapat diimplementasikan dan sebanyak $47 \%$ menilai setuju bahwa ilmu yang didapat dapat diimplementasikan. 
6. Sebanyak $47 \%$ peserta menilai sangat setuju untuk kegiatan ini dilaksanakan lagi di waktu mendatang dan sebanyak $53 \%$ menilai setuju untuk kegiatan ini dilaksanakan lagi di waktu mendatang.

7. Kesan, pesan dan saran dari peserta yang disampaikan secara deskriptif, dapat dikelompokkan ke dalam poinpoin di bawah ini :

a. Kegiatan ini sangat baik, sangat bagus, dan sangat memberikan inspirasi sekaligus memberikan berbagai inspirasi bagi peserta.

b. Kegiatan ini sangat bermanfaat sehingga di sarankan agar dapat dilaksanakan kembali di waktu mendatang.

c. Kegiatan ini sangat membantu membuka wawasan mengenai peluang-peluang untuk memiliki hidup yang lebih baik dengan melakukan bisnis secara online.

d. Kegiatan ini dapat menjadi ajang silaturahmi dari lingkungan akademik ke masyarakat umum, sehingga sangat membantu untuk menghilangkan batas-batas antara lingkungan akademik dengan masyarakat umum yang tidak sempat mengecap pendidikan tinggi.

\subsection{Aktifitas Kegiatan Pengabdian}

Beberapa dokumentasi kegiatan pengabdian yang dilakukan:
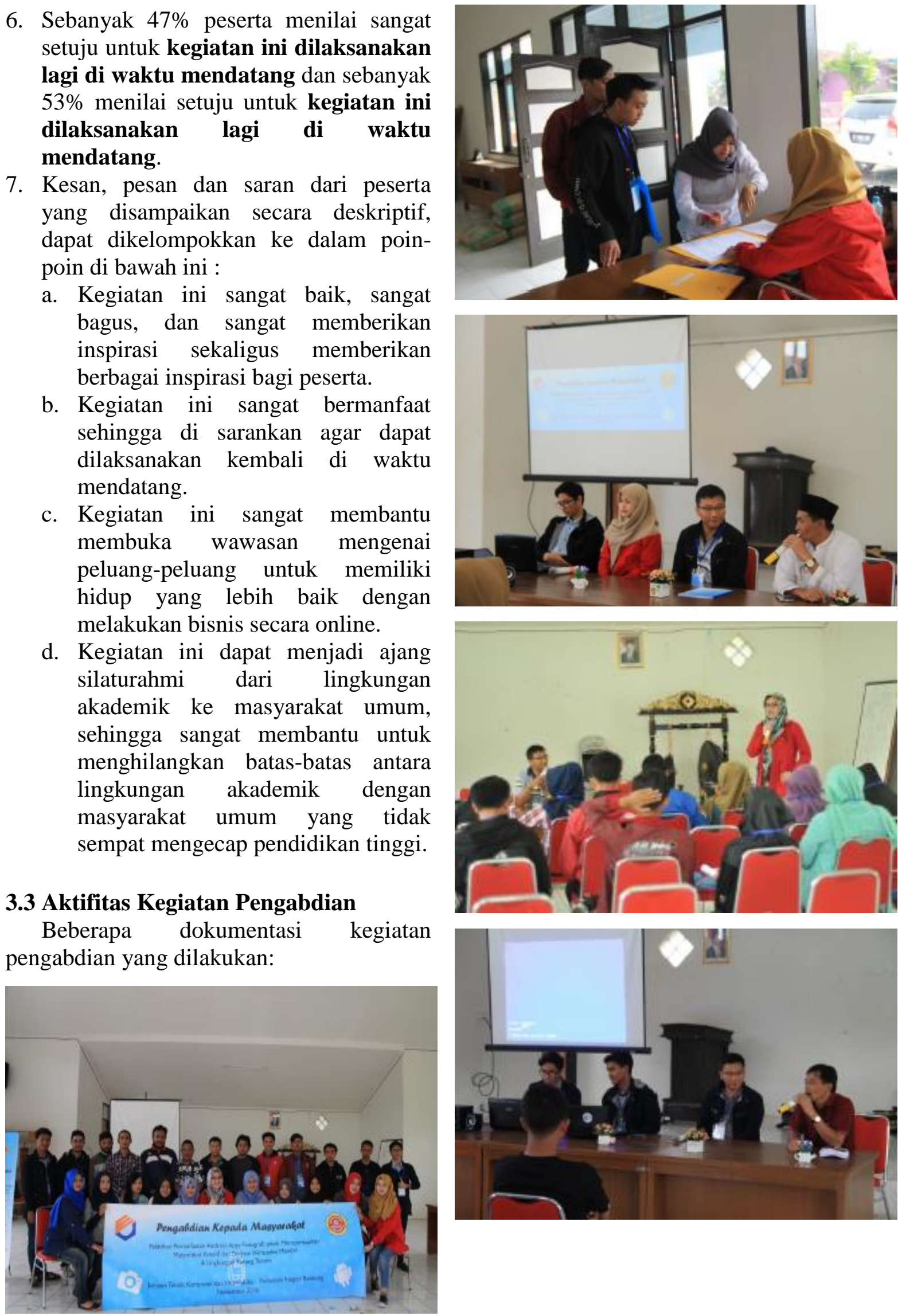


\section{KESIMPULAN}

Kesimpulan yang dapat diambil dari kegiatan pengabdian ini adalah:

1. Sebanyak $92 \%$ peserta menilai kegiatan terlaksanakan dengan sangat baik dan sebanyak $8 \%$ menilai kegiatan terlaksana dengan baik.

2. Sebanyak $5 \%$ peserta menilai materi yang diberikan sangat baik dan sebanyak $95 \%$ menilai materi yang diberikan baik.

3. Sebanyak $5 \%$ peserta menilai pemateri menyampaikan materi dengan sangat baik dan sebanyak $95 \%$ menilai pemateri menyampaikan materi dengan baik.

4. Sebanyak $47 \%$ peserta menilai sangat setuju bahwa kegiatan ini sangat bermanfaat dan sebanyak $53 \%$ menilai setuju bahwa kegiatan ini bermanfaat.

5. Sebanyak $47 \%$ peserta menilai sangat setuju bahwa ilmu yang didapat dapat diimplementasikan dan sebanyak $47 \%$ menilai setuju bahwa ilmu yang didapat dapat diimplementasikan.

6. Sebanyak $47 \%$ peserta menilai sangat setuju untuk kegiatan ini dilaksanakan lagi di waktu mendatang dan sebanyak $53 \%$ menilai setuju untuk kegiatan ini dilaksanakan lagi di waktu mendatang.

\section{SARAN}

1. Kegiatan sharing atau membagikan pengetahuan dari lingkungan akademisi ke masyarakat secara langsung, merupakan kegiatan yang sangat baik dan perlu dilakukan secara terus menerus dan berkesinambungan.

2. Perlu peran serta dari semua pihak untuk membantu masyarakat secara keseluruhan dalam mempersiapkan diri menghadapi perkembangan teknologi yang demikian cepat. Pemanfaatan teknologi di satu sisi dapat menjadi suatu keuntungan jika dimanfaatkan dengan baik dan maksimal, namun di sisi yang lain, perlu ilmu atau pengetahuan yang mumpuni agar teknologi tersebut dapat digunakan dengan baik, sehingga perlu dibuat program-program kegiatan serupa dari berbagai pihak terkait.

\section{REFERENSI}

Anon., t.thn. [Online]

Available at:

https://id.wikipedia.org/wiki/Karang_Tarun a

[Diakses 19 Maret 2016].

Anon., t.thn. [Online]

Available at:

http://www.hukumonline.com/klinik/detail/1 t52ef26d6b1e2e/dasar-hukum-karangtaruna

[Diakses 19 Maret 2016].

Anon., t.thn. [Online]

Available at:

http://www.bandungbaratkab.go.id/

[Diakses 19 Maret 2016].

Anon., t.thn. [Online]

Available at:

https://id.wikipedia.org/wiki/Kabupaten_Ba ndung Barat

[Diakses 19 Maret 2016].

Anon., t.thn. [Online]

Available at:

http://jabarprov.go.id/index.php/potensi_dae rah/detail/173/2

[Diakses 19 Maret 2016].

Anon., t.thn. [Online]

Available at:

http://bandung.panduanwisata.id/pegununga

n-kapur-padalarang/

[Diakses 19 Maret 2016].

Anon., t.thn. [Online]

Available at:

http://www.bandungbaratkab.go.id/content/ potensi-industri

[Diakses 19 Maret 2016].

Anon., t.thn. [Online]

Available at:

https://play.google.com/store/apps/details?i

$\mathrm{d}=$ com.motionone.stickit\&hl=en

[Diakses 19 Maret 2016].

Anon., t.thn. [Online]

Available at:

https://play.google.com/store/apps/details?i

$\mathrm{d}=$ com.advasoft.touchretouch\&hl=en

[Diakses 19 Maret 2016]. 
DIFUSI

Volume 1, No. 2, Juli 2018

Anon., t.thn. [Online]

Available at:

$\mathrm{d}=$ com.picsart.studio\&hl=en

https://play.google.com/store/apps/details?i

[Diakses 19 Maret 2016].

$\mathrm{d}=$ com.handycloset.android.eraser\&hl=en

Anon., t.thn. [Online]

[Diakses 19 Maret 2016].

Anon., t.thn. [Online]

Available at:

https://play.google.com/store/apps/details?i

$\mathrm{d}=$ com.instacut $2 \& \mathrm{hl}=\mathrm{en}$

Available at:

[Diakses 19 Maret 2016].

https://www.maxmanroe.com/wanabi-printpeluang-usaha-jasa-percetakan-digital.html [Diakses 19 Maret 2016].

Anon., t.thn. [Online]

Available at:

https://play.google.com/store/apps/details?i

Haris, A., 2014. Memahami Pendekatan

Pemberdayaan Masyarakat Melalui

Pemanfaatan Media. JUPITER, XIII(2), pp. 50-62.

Hong, J., 2010. Nonaka's Knowledge

Creation Model : Universal or

Particularistic. 